\title{
Prevalence of Anti-HBc Total Positivity in an Impoverished Urban Community in Bangladesh
}

\author{
Ghosh DK ${ }^{1}$, Ghosh $\mathrm{CK}^{2}$, Nath $\mathrm{M}^{3}$, Safwath $\mathrm{SA}^{4}$, Saha $\mathrm{SK}^{5}$, Rowshon $\mathrm{AHM}^{1}$ \\ ${ }^{I}$ Deptt. of Gastroenterology, Shaheed Suhrawardy Medical College\& Hospital, Dhaka, Bangladesh \\ ${ }^{2}$ Deptt. of Gastroenterology, Bangabandhu Sheikh Mujib Medical University, Dhaka, Bangladesh \\ ${ }^{3}$ Deptt. of Emergency, Shaheed Suhrawardy Medical College Hospital, Dhaka, Bangladesh \\ ${ }^{4}$ Deptt. of Gastroenterology, Jalalabad Ragib Rabeya Medical College, Sylhet, Bangladesh \\ ${ }^{5}$ Deptt. of Paediatrics, National Center for Control of Rheumatic Fever \& Heart Disease, Bangladesh
}

email: dkghoshmukta@gmail.com

\begin{abstract}
The infection with the Hepatitis B virus (HBV) is a global health problem. Hepatitis B virus (HBV) infections are rapidly spreading in developing countries due to the lack of health education, poverty, illiteracy and Hepatitis B vaccination. No widespread population based data of HBV is available in the country. So, a population-based serological survey was done to determine the prevalence of the Hepatitis B core antibody total (IgM+IgG) in an impoverished Urban Community in Dhaka, Bangladesh. A descriptive cross sectional study was conducted among 384 healthy individuals and age between 18-60 years from the urban slum in Dhaka city. The study was implemented through collaboration with Shaheed Suhrawardy Medical College, Dhaka from January 2013 to June 2013. The study participants were selected through systematic sampling procedure and blood samples tested for anti-HBc. Anti-HBc estimations were carried out by VITROS Immune diagnostic assay. The study was obtained ethical permission from Bangladesh Medical Research Council (BMRC) and every participant was informed regarding the study, and written informed consent was taken. Among the 384 respondents, 183(47.6\%) individuals were positive for the core antibody of hepatitis B virus (anti-HBc). The anti HBc positive group consisted almost of equal number of male 93, $(24.2 \%)$ and female 90 (23.4\%). There was a significantly increasing prevalence of the core antibody among young adults and middle age of the respondents $(28.7 \%)$. Major risk factors for exposure to Hepatitis B appeared to be ear-nose-body piercing, Circumcision by Hajam, unsafe blood transfusion and unsterile dental intervention. High prevalence of hepatitis B core antibody (47.6\%) indicates that the members of this urban community are highly exposed to hepatitis B virus.
\end{abstract}

Keywords: Anti-HBc total, Hepatitis B virus surface antigen (HBsAg), Immunoassay

\section{Introduction}

Chronic HBV infection is a serious clinical problem because of its worldwide distribution and potential adverse outcomes, including cirrhosis, hepatic decompensation, and hepatocellular carcinoma (HCC). HBV infection is particularly important in the Asian-Pacific region, where it is endemic, with the majority of infections being acquired perinatally or in early childhood. ${ }^{1}$

The prevalence of chronic HBV infection varies geographically, from high $(>8 \%)$, intermediate $(2-7 \%)$ to low $(<2 \%){ }^{2}$ Whereas in India, carrier rate of $3 \%$, contributes nearly $10 \%$ of the HBV carriers in the world. About one million HBV infections are added to the HBV pool in India yearly, contributing to its rapid expansion. ${ }^{3,4}$ Among the Filipino blood donors HBV was found $4.2 \% .^{5}$ Prevalence is low, $<1 \%$ in Australia and New Zealand, 1-5\% in Japan, Singapore and Thailand. 6-8\% in Indonesia, Northern China and highest, $10 \%$ in Taiwan, Southern China, Korea, Philippines and malaysia. ${ }^{6}$

The World Health Organization ranked Bangladesh, moderate to high-risk group of countries for HBV infection, where the prevalence of $\mathrm{HBV}$ is $19 \%$ to $29 \%$ among professional donors and $2.4 \%$ among voluntary donors. Seropositivity for HBsAg reported in another study among professional blood donors 
was $19.6 \%$, replacement blood donors $9 \%$ and the voluntary blood donors was $10 \% .^{7}$ Another report revealed that the HBV prevalence in Bangladesh is 2.3 to 9.7 percent with an approximate carrier pool of 10 million. These include healthy adult population 4.4 to $9.7 \%$, healthy children $3 \%$, school girls $2.3 \%$, a rural community $6.4 \%$, and slum communities $3.8 \%$. Vertical transmission of HBV in Bangladesh is infrequent due to a low $\mathrm{HBsAg}$ positivity rate (30.1\%) among pregnant females with HBV infection. ${ }^{8-9}$

There is paucity of information on the prevalence of HBV infections among General population in Bangladesh and majority of the previous studies are conducted in selected group of people with higher risk factors such as blood donors, drug addicts, commercial sex workers (CSWs) or hospitalized patients. ${ }^{8-12}$ However, a recent report revealed $5.5 \%$ HBsAg positivity among the general population living in Savar region, a semiurban area on the outskirts of Dhaka. ${ }^{13}$

Due to lack of literacy, there is a lack of access to health information like health safety, mode of transmission of diseases, un-safety associated with blood transfusion practice, un-sterile injection, unsafe sex practice, unhealthy living conditions etc. adversely affecting individual's physical health leading to different diseases like HBV infection in Bangladesh. ${ }^{14}$ The anti-HBc antibody is an important marker for surveying the burden of HBV infection as it persists even after resolution of infection, and thus identifies both past and current $\mathrm{HBV}$ infection. ${ }^{15}$

So, the study was designed to estimate the prevalence of anti-HBc total positivity among impoverished urban population of Dhaka city in Bangladesh and attempted to identify the gravity and magnitude of hepatitis B virus infection among the general population.

\section{Materials and Methods}

This cross sectional study was conducted in collaboration with Department of Gastroenterology, Shaheed Suhrawardy Medical College, Dhaka from January 2013 to June 2013 among Kalyanpur slum (porabosti) at Dhaka.

Bangladesh Bureau of Statistics (BBS), 2011 stated that Kalyanpur slum (porabasti) which is situated at Kalyanpur mahalla under Kalyanpur ward of Mirpurthana in Dhaka district. There are eight wards and 57 mahallas in this thana. Among eight wards, Kalyanpur ward is situated in ward no.11. This ward is divided into four mahallas. BBS report, 2015 also referred that the total population of Kalyanpur mahalla is 42,801 , while male population was $55.8 \%$, and female population was $44.2 \%$. The total household and population of Kalyanpur slum (porabasti) was 2,184 and 8,129 (male 4,126, female 3,998 and others 5), respectively. In this study, 384 healthy individuals of either sex aged between 18-60 years were included. Respondents not willing to participate in the study were excluded.

Systematic sampling technique was adopted for the study. From the sampling frame, a starting point is chosen at random, and choices thereafter are at regular intervals. In this study, first sample was randomly selected then every fifth individual was selected as sampling interval.

During data collection, trained field research assistants (FRAs) were visited the selected households in accordance with the systemic randomization list and approached the head of the family and explained the purpose and objective of the study through obtained written informed consent from. Prior to the commencement of this study, the research protocol was approved by National Research Ethics Committee (NREC) of BMRC. Research physicians were collected $4 \mathrm{ml}$ of blood from the anti cubital veins under aseptic conditions. The blood specimens were transported to Popular Diagnostic Centre Ltd. Shantinagar, Dhaka and centrifuged within 6 hours and stored at $-20^{\circ} \mathrm{C}$ in aliquots. Anti $\mathrm{HBc}$ estimation was carried out by VITROS Immuno diagnostic assay. A Result of $<1.00$ indicates a reactive sample and the possible presence of anti$\mathrm{HBc}$ and $\geq 1.20$ indicates a non-reactive sample, negative for anti-HBc.

All the relevant collected data were compiled on a master chart first and then statistical analysis of the results was obtained by using window based computer software device with Statistical Packages for Social Sciences (SPSS-17.0) (SPSS Inc, Chicago, IL, USA). The result was presented as odd ratios with $95 \%$ confidence intervals. A two- sided $p$ value less than 0.05 was regarded as statically significant, and $95 \%$ confidence 
intervals was computed using a logistic regression model.

\section{Results}

Study population consisted of 384 respondents, $174(45.3 \%)$ male and $210(54.7 \%)$ female. The majority $148(38.5 \%)$ of the study population belonged to middle age group of up to 30 years and the mean age of them was 31 years. The male to female ratio in percentage was 16.9: 21.6. In this study, $318(82.8 \%)$ of the participants were married whereas $194(50.5 \%)$ were female and $124(32.3 \%)$ were male. In regards to the occupation of the respondents, majority were housewives 108 (28.1\%), about 103 (26.8\%) from daily laborers and about 125 (32.6\%) constituted other occupation like, garment workers, students, teachers and self-employed. In respects of the educational background, more than $200(52.1 \%)$ of the respondents were illiterate and the next highest group 87 (22.7\%) read up to class $\mathrm{V}$. The highest literate women group $57(14.8 \%)$ belonged to class I-V. About $190(49.5 \%)$ of the respondents reported to earn a monthly income of BDT. 3001- 4000 with an average income BDT. 4,170. Although the average income of men (BDT. 4,370) was a bit higher than that of women (BDT. 4,003). (tableI \& II).

Table I: Percentage distribution of demographic/ socio-economic characteristics of the respondents $(n=384)$

\begin{tabular}{lccc}
\hline i. Age Groups & Male(174) & Female(210) & Total (384) \\
\hline$<20$ & $34(8.9 \%)$ & $53(13.8 \%)$ & $87(22.7 \%)$ \\
$21-30$ & $65(16.9 \%)$ & $83(21.6 \%)$ & $148(38.5 \%)$ \\
$31-40$ & $37(9.6 \%)$ & $44(11.5 \%)$ & $81(21.1 \%)$ \\
$41-50$ & $19(5.0 \%)$ & $22(5.7 \%)$ & $41(10.7 \%)$ \\
$51+$ & $19(5.0 \%)$ & $8(2.1 \%)$ & $27(7.0 \%)$ \\
Total & $174(45.3 \%)$ & $210(54.7 \%)$ & $384(100 \%)$ \\
Mean Age (years) & $\mathbf{3 2 . 1 7}$ & $\mathbf{3 0 . 2 3}$ & $\mathbf{3 1 . 1 1}$ \\
ii. Marital Status & & & $318(82.8 \%)$ \\
Married & $124(32.3 \%)$ & $194(50.5 \%)$ & $66(17.2 \%)$ \\
Unmarried & $50(13.0 \%)$ & $16(4.2 \%)$ & $\mathbf{3 8 4}(\mathbf{1 0 0 \%})$ \\
Total & $\mathbf{1 7 4}(\mathbf{4 5 . 3 \%})$ & $\mathbf{2 1 0}(\mathbf{5 4 . 7 \%})$ & $21(5.5 \%)$ \\
iii.Occupation & & & $27(7.0 \%)$ \\
Service & $10(2.6 \%)$ & $11(2.9 \%)$ & $108(28.1 \%)$ \\
Business & $24(6.3 \%)$ & $3(1.0 \%)$ & $103(26.8 \%)$ \\
House wife & $0,(0.00 \%)$ & $108(28.1 \%)$ & $125(32.6 \%)$ \\
Daily Laborer & $63(16.4 \%)$ & $40(10.4 \%)$ & $\mathbf{3 8 4}(\mathbf{1 0 0 \%})$ \\
Others & $77(20.1 \%)$ & $48(12.5 \%)$ & $200(52.1 \%)$ \\
Total & $\mathbf{1 7 4}(\mathbf{4 5 . 3 \%})$ & $\mathbf{2 1 0}(\mathbf{5 4 . 7 \%})$ & $87(22.7 \%)$ \\
iv. Education & & & $40(10.4 \%)$ \\
Illiterate & $84(21.9 \%)$ & $116(30.2 \%)$ & $11(2.9 \%)$ \\
Class I-V & $30(7.8 \%)$ & $57(14.8 \%)$ & $46(12.0 \%)$ \\
Class VI-IX & $22(5.7 \%)$ & $18(4.7 \%)$ & $\mathbf{3 8 4}(\mathbf{1 0 0 \%})$ \\
SSC \& equivalent & $8(2.1 \%)$ & $3(1.0 \%)$ & $79(20.6 \%)$ \\
HSC \& equivalent & $30(7.8 \%)$ & $16(4.2 \%)$ & $190(49.5 \%)$ \\
Total & $\mathbf{1 7 4}(\mathbf{4 5 . 3 \% )}$ & $\mathbf{2 1 0}(\mathbf{5 4 . 7 \% )}$ & $82(21.4 \%)$ \\
v. Monthly family Income & & & $33(8.6 \%)$ \\
Tk 2000-3000 & $28(7.3 \%)$ & $51(13.3 \%)$ & $384(100 \%)$ \\
Tk3001-4000 & $75(19.5 \%)$ & $115(30.0 \%)$ & $\mathbf{4 , 1 7 0}$ \\
Tk4001-5000 & $47(12.2 \%)$ & $35(9.1 \%)$ & $9(2.3 \%)$ \\
Tk5000+ & $24(6.3 \%)$ & $210(54.7 \%)$ & $\mathbf{4 , 0 0 3}$ \\
Total & $174(45.3 \%)$ & & \\
Mean Income & $\mathbf{4 , 3 7 0}$ & & \\
\hline
\end{tabular}


Table II: Percentage distribution of respondents by monthly family income, education and occupation ( $\mathrm{n}=384)$.

\begin{tabular}{llllll}
\hline i. $\quad$ Education & \multicolumn{9}{l}{ Average monthly family Income (Tk.) } & & Total \\
\hline Illiterate & $2000-3000$ & $3001-4000$ & $4001-5000$ & $5000+$ & 52.1 \\
Class I-V & 16.7 & 28.6 & 5.5 & 1.3 & 22.6 \\
Class VI-IX & 3.4 & 13.5 & 5.5 & 0.2 & 10.4 \\
SSC \& equivalent & 0.2 & 4.2 & 5.2 & 0.8 & 2.9 \\
HSC \& equivalent & 0.3 & 0.5 & 1.3 & 0.8 & 12.0 \\
Total & 0.0 & 2.6 & 3.9 & 5.5 & 100.00 \\
$\quad$ ii. Occupation & 20.6 & 49.4 & 21.4 & 8.6 & Total \\
& & & & & 5.5 \\
Service & $2000-3000$ & $3001-4000$ & $4001-5000$ & $5000+$ & 7.1 \\
Business & 0.0 & 0.0 & 3.4 & 2.1 & 28.1 \\
House wife & 0.3 & 2.9 & 2.9 & 1.0 & 26.8 \\
Daily Laborer & 5.2 & 19.5 & 3.4 & 0.00 & 32.5 \\
Others & 12.0 & 12.2 & 2.6 & 0.00 & 100.00 \\
Total & 3.1 & 14.8 & 9.1 & 5.5 & 8.6 \\
\hline
\end{tabular}

Among 384 study population, $183(47.7 \%)$ belonged to anti $\mathrm{HBc}$ positive group against 201 (52.3\%) persons possessing the anti $\mathrm{HBc}$ negativity test results. The anti $\mathrm{HBc}$ positive group consisted almost of equal number of male $93(24.2 \%)$ and female $90(23.4 \%$, table-III).

Table III: Distribution of respondents by Anti HBc status by

\begin{tabular}{|c|c|c|c|c|c|c|}
\hline \multirow[t]{2}{*}{ Sex } & \multicolumn{2}{|c|}{$\begin{array}{c}\text { Anti HBc } \\
\text { Positive }\end{array}$} & \multicolumn{2}{|c|}{$\begin{array}{c}\text { Anti HBc } \\
\text { Negative }\end{array}$} & \multicolumn{2}{|c|}{ Total } \\
\hline & Number & $\%$ & Number & $\%$ & Number & $\%$ \\
\hline Male & 93 & 24.2 & 81 & 21.1 & 174 & 45.3 \\
\hline Female & 90 & 23.4 & 120 & 31.3 & 210 & 54.7 \\
\hline Total & 183 & 47.6 & 201 & 52.4 & 384 & 100.0 \\
\hline
\end{tabular}

In this study, the bivariate analysis of tested anti HBc positivity, four risk factors along with

Table IV: Bivariate analysis for significant risk factors for tested Anti HBc positivity $(\mathrm{n}=384)$

\begin{tabular}{|c|c|c|c|c|}
\hline Risk factors & $\begin{array}{l}\text { Anti HBc } \\
\text { Positive (183) }\end{array}$ & $\begin{array}{l}\text { Anti HBc Negative } \\
\text { (201) }\end{array}$ & $\begin{array}{l}\text { Odd Ratio (at } 95 \% \\
\text { Confidence Interval) }\end{array}$ & $p$-value \\
\hline \multicolumn{5}{|l|}{ 1.Education } \\
\hline Level 1-Illiterate & $106(24.4 \%)$ & $94(27.6 \%)$ & $0.223(.093-.534)$ & .001 \\
\hline Level 2-Class I-V & $41(12.0 \%)$ & $46(10.7 \%)$ & $0.184(.071-.476)$ & .000 \\
\hline Level 3-Class VI-IX & $22(4.7 \%)$ & $18(5.7 \%)$ & $0.158(.055-.449)$ & .001 \\
\hline \multicolumn{5}{|c|}{ 2.History of Dental Procedure } \\
\hline Present & $45(24.6 \%)$ & $25(12.4 \%)$ & $0.433(.251-.746)$ & .003 \\
\hline Absent & $138(75.4 \%)$ & $176(87.6 \%)$ & & \\
\hline \multicolumn{5}{|c|}{ 3.History of Blood transfusion } \\
\hline Present & $9(4.9 \%)$ & $3(4.9 \%)$ & $0.187(.041-.855)$ & .015 \\
\hline Absent & $174(95.1 \%)$ & $198(95.1 \%)$ & & \\
\hline \multicolumn{5}{|c|}{ 4.History of Ear-nose-body piercing } \\
\hline Present & $96(52.5 \%)$ & $116(57.7 \%)$ & $0.453(.209-.980)$ & 0.044 \\
\hline Absent & $87(47.5 \%)$ & $85(42.3 \%)$ & & \\
\hline \multicolumn{5}{|c|}{ 5.History of Circumcision by Hajam } \\
\hline Present & $93(50.8 \%)$ & $77(38.3 \%)$ & $0.322(.149-.696)$ & 0.004 \\
\hline Absent & $90(49.2 \%)$ & $124(61.7 \%)$ & & \\
\hline
\end{tabular}

Multinomial logistic regression analysis results were showed the similar findings of bivariate analysis except education. (table-V). educational background of the respondents were identified to be significantly associated. The Odd Ratio (OR) and p-values (p) respectively of those were: education level 1 (Illiterate) $-\mathrm{OR}=.223$; $\mathrm{p}=.001$, education level 2 (Class I-V) $-\mathrm{OR}=.184$; $\mathrm{p}=.000$, education level 3 (Class VI-IX) $\mathrm{OR}=.158 ; \mathrm{p}=.001$, History of dental procedure 45 (24.6\%); OR=.433; $\mathrm{p}=.003$, History of Blood Transfusion 9 (4.9\%); - OR=.187; p=.015, History of Ear-nose-body piercing 96 (52.5\%) $\mathrm{OR}=.453, \mathrm{p}=.044$ and History of Circumcision by Hajam 93 (50.8\%);- OR=.322; $\mathrm{p}=.004$ were significant among the anti $\mathrm{HBc}$ positive individuals (table-IV). 
Table V: Multinomial logistic regression analysis for significant risk factors for tested Anti HBc positivity

\begin{tabular}{|c|c|c|c|c|}
\hline Risk factors & $\begin{array}{l}\text { Anti HBc Positive } \\
(183)\end{array}$ & $\begin{array}{l}\text { Anti HBc Negative } \\
\text { (201) }\end{array}$ & $\begin{array}{l}\text { Odd Ratio (at 95\% } \\
\text { Confidence Interval) }\end{array}$ & p-value \\
\hline Dental Procedure & $45(24.6 \%)$ & $25(12.4 \%)$ & $\begin{array}{l}0.433 \\
(0.251-0.746)\end{array}$ & 0.003 \\
\hline Blood Transfusion & $9(4.9 \%)$ & $3(4.9 \%)$ & $\begin{array}{l}0.187 \\
(0.041-0.855)\end{array}$ & 0.015 \\
\hline Ear-nose-body piercing & $96(52.5 \%)$ & $116(57.7 \%)$ & $\begin{array}{l}0.453 \\
(0.209-0.980)\end{array}$ & 0.044 \\
\hline Circumcision by Hajam & $93(50.8 \%)$ & $77(38.3 \%)$ & $\begin{array}{l}0.322 \\
(0.149-0.696) \\
\end{array}$ & 0.004 \\
\hline
\end{tabular}

\section{Discussion}

Prevalence studies are not always easily undertaken in the developing countries including Bangladesh due to high cost, we made efforts to prospectively estimate Prevalence of anti-HBC total positivity among a population living at Kalyanpur, a densely populated community in Dhaka, the capital city of Bangladesh.The results of our study suggest a high HBV exposure among our study population.

In this study, 384 respondents were tested for the Hepatitis B core antibody. Among them 183(47.7\%) were positive and 201(52.3\%) were negative. The anti HBC positive group consisted almost of equal number of male $(24.2 \%)$ and female $(23.4 \%)$. The prevalence of Hepatitis B core antibody (anti-HBc) was $47.7 \%$ among our study population. It was higher to that reported from previous study of healthy adult and children in Bangladesh $(21.1 \%)$ but within the range of previous studies from selected population of Dhaka; $24.1 \%$ in non-Intravenous Drug Users (NIDUs) and $31.8 \%$ in Intravenous Drug Users(IDUs); $35.2 \%$ among women at a Sexually Transmitted Disease (STD)clinic ; 48.1\% among truck drivers and helpers ; $49.3 \%$ among women living near a truck stand; and 73\% among Commercial Sex Workers (CSWs). ${ }^{16-21}$.The higher rates among our study population could be attributed to the general lack of proper health care because of deprived socio-economic status (monthly household income of US \$ 50) and less public health awareness about the transmission of Hepatitis B Virus infection as well as the lack of hepatitis B vaccination in the community.

The varied prevalence of the anti $\mathrm{HBc}$, a marker for exposure to $\mathrm{HBV}$ infection has been reported from different parts of India, ranging between $8 \%-18 \%$ of total donor population. ${ }^{22}$ In the study from Behrampur, Ganjam in Orissa, about $30.1 \%$ of total donations (220 of 729) was anti HBc positive indicating a very high rate of exposure to
HBV infection among the blood donors from this region. Studies from other parts of India reported that the prevalence of anti HBV core antibody ranging from $21 \%$ in Kolkata (Eastern India), $20.9 \%$ in New Delhi (Northern India) to $8.4 \%$ in Chandigarh (Northwestern India). ${ }^{23,24}$

The socio-demographic analysis of the 183 responded who were positive for anti- $\mathrm{HBc}$ antibody showed that it had a higher preponderance in female $(7.3 \%$ in males Vs $8.6 \%$ in females). A study was conducted in India by Asim et al. which showed a difference in the sero prevalence of the core antibody between the male and the female donors (19.3\% Vs 18\%), but as in our study, the difference was statistically not significant. $^{25}$ We observed a significantly increasing prevalence of the core antibody was among young adults and middle age individuals. Almost equal percent of anti $\mathrm{HBc}$ positive cases was observed in the illiterate males and females. This favors horizontal transmission in early childhood as the principal mode of transmission of the virus, contrary to vertical transmission, which is popularly assumed. Similar observations have also been made in Nepal and India. ${ }^{26,27}$ Overcrowding and poor levels of sanitation may be responsible for such early horizontal spread of the virus.

The risk factors for exposure to HBV as revealed by this study, include History of Dental procedure (OR .433; $\mathrm{p}=.003$ ), History of Blood Transfusion (OR .187; p=.015), Ear-nose-body piercing (OR .453; $\mathrm{p}=.044)$ and Circumcision by Hajam (OR .322; $\mathrm{p}=.004$ ). The most important risk factor for HBV as revealed by the study, include dental procedure and circumcision by Hajam who were unaware of the consequences of unhygienic and unsterilized intervention. Blood transfusion is another important risk factor for HBV transmission revealed by the study. The screening of the blood units for the core antibody adds to the cost, but it is definitely useful in reducing the residual risk of post transfusion 
hepatitis. The traditional practice of ear and nose piercing by women is also an important route of HBV transmission and thus extra care is warranted before one pierces a tissue.

HBV poses a huge burden on the health of Bangladeshis, being the leading cause of all forms of chronic liver diseases (CLD). HBV is responsible for $76.3 \%$ of cases of chronic hepatitis and $61.2 \%$ of cases of cirrhosis. ${ }^{28,29}$ Things have changed very little over the years, as a Bangladeshi study in 1994, found that HBV responsible for $40.5 \%$ of cases of CLD in this country. ${ }^{30}$ In India $>60 \%$ of cases of CLD is due to HBV. ${ }^{31}$ The same applies to Pakistan, where $\mathrm{HBV}$ is responsible for $60 \%$ of cases of CLD. ${ }^{32} \mathrm{In}$ Nepal, $60 \%$ of cases of chronic hepatitis and $40 \%$ of cases of cirrhosis of the liver are due to HBV. ${ }^{33}$

HBV also ranks the first as the cause of Hepato Cellular Carcinoma (HCC) in Bangladesh. Studies have shown that HBV is responsible for $33.3 \%$ of cases of HCC in Bangladesh. ${ }^{34}$

The intermediate rate of chronic HBV carriage of around 3\% was observed in most general populations (clinics, villagers), suggesting that this population would benefit from universal hepatitis B vaccination. ${ }^{35}$ In 2004, the Government of Bangladesh and United Nation International Children Emergency Fund (UNICEF) have introduced the hepatitis B vaccine into the Expanded Programme on Immunization (EPI) against six infectious diseases. The successful continuation of the programme is expected to reduce chronic HBV infections in the next generations. Since $90 \%$ of the HBV infected older children and adults successfully clear the infection and do not become chronic carriers, the prevalence of HBsAg alone might not describe the total burden of HBV infections.

Therefore, estimation of the prevalence of anti$\mathrm{HBc}$, in addition to the estimation of the prevalence of HBsAg which is the most reliable biological biomarker of HBV infection, is much more informative about indicator of HBV disease burden among the population.

There are some limitations of this study. First, it could not be performed surface Antigen tests for HBV (HBsAg) and HBV DNA the presence of which indicates current status of infection; and anti-HBs that differentiate susceptible persons from those immune persons, which can be due either to natural infection or hepatitis B vaccination. All the above limitations are mainly due to study cost constraints, mostly related to laboratory tests. The second limitation is that the study was conducted in a single population in Dhaka, and may not reflect all of Bangladesh, although the literature we have cited suggests that it should. A final limitation is the relatively short observation window, which may have missed important secular trends in the background prevalence of the hepatitis B viruses.

\section{Conclusion}

Based on the findings of the study, it may be concluded that high prevalence of Hepatitis B core antibody $(47.6 \%)$ indicates that the memebers of this urban community are highly exposed to hepatitis B virus.

\section{Acknowledgement}

Authors gratefully acknowledge the financial support of the BMRC for this research work for the benefit of mass population of the country. We also thankful to the study participants for their valuable time, support and cooperation.

\section{Reference}

1. Liaw YF. Antiviral therapy of chronic hepatitis B: opportunities and challenges in Asia. J Hepatol 2009;51:403-410.

2. Jilin Hou, Zhihua Liu, Fan G: Prevalence of Hepatitis B virus Infection. Int J Med Sci. 2005; 2: 50-57.

3. Bharat S, Monika V, Karttikaye V. The markers for transfusion-associated hepatitis in north Indian blood donors: the prevalence and the trends. Jpn J Infect Dis.2004;57:49-51.

4. Abhijit Chowdhury et, al. Department of Gastroenterology, Institute of Post Graduate Medical Education and Research. Journal of Gastroenterology and Hepatology, November 2005, India.

5. Yanase Y, Ohida T, Kaneite Y, Aqdamaq DM, Leano PS, Gill CJ: The prevalence of HIV: HBV and HCV among Filipino blood donors and overseas work visa applicants. 2007;85:131-7.

6. GC Farrel,Y-F Lian and GW McCaughan. Consensus on Hepatitis B and C. Consensus statement on the prevention and management of Hepatitis B and Hepatitis C in the Asia Pacific 
region. J. Gastroenterology and Hepatology. $2000 ; 15: 815-818$.

7. Mollah AH, Nahar N, Siddique MA, Anwar KS, Hassan T, Azam MG. Journal of Health, Population and Nutrition. 2003; 21: 67-71.

8. Islam MN, Islam KM, Islam N. Hepatitis-B virus infection in Dhaka, Bangladesh. Bangladesh Med Res Counc Bull 1984;10:1-6.

9. Rumi MA, Begum K, Hassan MS, Hasan SM, Azam MG, Hasan KN, Shirin M,Khan AK: Detection of hepatitis B surface antigen in pregnant women attending a public hospital for delivery: implication for vaccinationstrategy in Bangladesh. Am J Trop Med Hyg. 1998; 59:31822 .

10. Mustafa M, Islam MN, Rahman M, Salauddin AK: Prevalence of hepatitis B surface antigen (HBsAg) among parenteral drug abusers at Dhaka.Bangladesh Med Res Counc Bull. 1989; 15:1-7.

11. Ahmad Q, Chowdhury SG, Islam MN, Khan FD, Alam MR, Miah AH: HBsAg amongst unscreened operated patients. Bangladesh Med Res Counc Bull 1991; 17:11-16.

12. Sattar H, Islam MN. Hepatitis B virus markers among the prostitutes of Dhaka. Bangladesh Med Res Counc Bull. 1996;22:8-11.

13. Mahtab MA, Rahman S, Karim MF, Khan M, Foster G, Solaiman S, Afroz S: Epidemiology of hepatitis B virus in Bangladeshi general population. Hepato biliary Pancreat Dis Int. 2008; 7:595-600

14. SMR Islam, F Rahman, MMMR Siddiqui. Bangladesh is Experiencing Double Burden with Infectious Diseases and Non-communicable Diseases (NCD's): An Issue of Emerging Epidemics. AKMMC J. 2014; 5:46-50.

15. Deinhartd F: Serum markers of hepatitis viruses in natural disease and after vaccination. Prog Liver Dis 1982; 7:451-67

16. Zaki H, Darmstadt GL, Baten A, Ahsan CR, Saha SK: Seroepidemiology of hepatitis B and delta virus infections in Bangladesh. J Trop Pediatr 2003;49:371-4.

17. Shirin T, Ahmed T, Iqbal A, Islam M, Islam MN. Prevalence and risk factors of hepatitis B virus, hepatitis $\mathrm{C}$ virus, and human immune deficiency virus infections among drug addicts in
Bangladesh. J Health Popul Nutr 2000; 18:14550 .

18. Bogaerts J, Ahmed J, Akhter N, Begum N, Rahman M, Nahar S, Van Ranst M, Verhaegen J. Sexually transmitted infections among married women in Dhaka, Bangladesh: unexpected high prevalence of herpes simplex type 2 infection. Sex Transm Infect. 2001; 77:114-9.

19. Gibney L, Saquib N, Metzger J, Choudhury P, Siddiqui M, Hassan M. Human immunodeficiency virus, hepatitis B, C and D in Bangladesh's trucking industry: prevalence and risk factors. Int J Epidemiol. 2001; 30:878-84.

20. Gibney L, Macaluso M, Kirk K, Hassan MS, Schwebke J, VermundSH,Choudhury P. Prevalence of infectious diseases in Bangladeshi women living adjacent to a truck stand: HIV/STD/hepatitis/genital tract infections. Sex Transm Infect. 2001; 77:344-50.

21. Sattar H, Islam MN. Hepatitis B virus markers among the prostitutes of Dhaka, Bangladesh. Med Res Counc Bull. 1996; 22:8-11.

22. Dhawan HK, Marwaha N, Sharma RR, Chawla Y, Thakral B, Saluja K, Sharma SK, Thakur MK, Jain A. Anti-HBc screening in Indian blood donors Still an unresolved issue. World $\mathbf{J}$ Gastroenterol 2008; 14: 5327-5330.

23. Duseja A, Sharma S, Subramanian PG, Agnihotri SK, Chakraborti A, Chawla Y. Occult hepatitis B virus (HBV) infection in healthy blood donors. Indian J Pathol Microbiol. 2003; 46: 690-692.

24. Bhattacharya P, Chandra PK, Datta S, Banerjee A, Chakraborty S, Rajendran K, Basu SK, Bhattacharya SK, Chakravarty R. Significant increase in HIV, HBV, HCV and syphilis infections among blood donors in West Bengal, Eastern India 2004-2005. exploratory screening reveals high frequency of occult HBV infection. World J Gastroenterol 2007; 13: 3730-3733.

25. Asim M, Ali R, Khan LA, Husain SA, Singla R, Kar P. The significance of the anti-HBc screening of blood donors and its association with the occult hepatitis B virus infection: the implications for blood transfusion. Indian J Med Res. 2010; 132: 312-17.

26. Shrestha SM. Seroepidemiologyof Hepatitis B in Nepal. J Com Dis. 1990; 22 :27-32.

27. Tandon BN, Acarya SK, Tandon A, Seroepidemiology of HBV and HCV I India. Int Hepatol Comm 1996; 5:14-18.

28. Mahtab MA, Rahman S, Khan M, Kamal M, Karim MF, Ahmed F, Hussain MF, Podder PK 
Aetiology of chronic hepatitis in Bangladesh. Indian J Gastroenterol. 2007; 26(Suppl 2): 142

29. Afroz S, Mahtab MA, Rahman S, Khan M. Hepatitis B virus is the leading cause of cirrhosis of liver in Bangladesh. Hepatol Int. 2007; 1:120.

30. Mahtab MA, Kumar S, Rahman S, Kamal M, Khan M, Aggarwal R. Genotypes of hepatitis B virus among chronically infected patients in a tertiary care hospital in Bangladesh. Indian $\mathrm{J}$ Gastroenterol. 2006; 25: 219-21.

31. Acharya SK, Panda SK, Duphare H, Dasarathy S, Ramesh R, Jameel S, et al. Choronic hepatitis in a large Indian Hospital. Natl Med J India 1993; 6:202-206.
32. Zuberi SJ, Seroepidemiology of $\mathrm{HBV} / \mathrm{HCV}$ in Pakistan. Int Hepatol Comm. 1996; 5:19-26.

33. Shrestha SM, Tsuda F, Okamoto H, Tokita H, Horikita M, Tanaka T, et al. Hepatitis B virus subtypes and hepatitis $\mathrm{C}$ virus genotype in patient with chronic liver disease in Nepal. Hepatology. 1994; 19:805-809.

34. Khan M, Zaki KMJ, Ahmed KU, Clinical profile: Prognostic index in hepatocellular carcinoma. Bangladesh Med Res Council Bull. 1991; XVII:49-62.

35. Sabin KM, Rahman M, Hawkes S, Ahsan K, Begum L, Black RE, Baqui AH: Sexually transmitted infections prevalence rates in slum communities of Dhaka, Bangladesh. Int J STD AIDS. 2003; 14:614-21. 